\title{
How does a creative learning environment foster student creativity? An examination on multiple explanatory mechanisms
}

\author{
Mudan Fan ${ }^{1} \cdot$ Wenjing $\mathrm{Cai}^{2,3}$ (1) \\ Published online: 4 August 2020 \\ (C) The Author(s) 2020
}

\begin{abstract}
Scholars and educators have acknowledged the importance of the learning environment, especially the creative learning environment, on student creativity. However, the current understanding is far from complete to paint a clear picture of how a creative learning environment can stimulate students' creative outcomes in the classroom. Drawing on Amabile's componential theory of creativity, the present research aims to test how a creative learning environment can foster undergraduate creativity through three distinct mechanisms (i.e., learning goal orientation, network ties, and knowledge sharing). A total of 431 students and their teachers from a Chinese university completed questionnaires. The results generally supported the theoretical model in which a creative learning environment is significantly associated with student creativity by enhancing students' learning goal orientation, network ties, and knowledge sharing. Implications for theory and educational practice, limitations of the present study, and suggestions for future research are discussed.
\end{abstract}

Keywords Creative learning environment $\cdot$ Learning goal orientation $\cdot$ Network ties, knowledge sharing $\cdot$ Student creativity

\section{Introduction}

Creativity is becoming increasingly important in modern society (Beghetto and Kaufman 2014; Richardson and Mishra 2018; Yeh et al. 2012). Specifically, as students are the key drivers of societal development, universities around the world have been taking on the mission of fostering creative individuals and producing creativity. Accordingly, researchers and educators are attempting to identify predictors that facilitate student creativity, such as teacher behaviors (e.g., encouragement and other teacher behaviors) (Chan and Yuen 2014). More recently, researchers have begun investigating the role of the classroom environment (Tsai et al. 2015). Notably missing from the literature is a thorough examination of the creative learning environment, despite suggestions by scholars that student creativity can be nurtured by educators who focus greater effort on building a learning environment that highlights the value of creativity (Davies et al. 2013;

Wenjing Cai

w.cai@vu.nl

1 School of Education, Weinan Normal University, Weinan, People's Republic of China

2 School of Public Affairs, University of Science and Technology of China, Hefei, People's Republic of China

3 Department of Management and Organization, Vrije Universiteit Amsterdam, Amsterdam, the Netherlands
Richardson and Mishra 2018). Therefore, a major purpose of this study is to address the connection between a creative learning environment and student creativity by identifying several important intervening mechanisms.

In building a model linking a creative learning environment and creativity, we further draw on the dynamic componential theory of creativity (Amabile and Pratt 2016), which suggests that desirable contexts can induce creativity by influencing multiple personal motivations and behaviors. This foundational theory highlights the exploration of personal motivations and social exchanges as mediators in creativity research. Thus, I propose three mediating mechanisms with high potential to help explain the linkage: learning goal orientation, network ties, and knowledge sharing. Specifically, learning goal orientation, referring to students who believe in learning, understanding, and development as ends in themselves (Lerang et al. 2019), illustrates students' internal motivation in seeking knowledge to produce creative outputs (D'Lima et al. 2014). As the framework of achievement goal theory highlighting both the personal and contextual aspects of goals, creativity scholars have found that the learning environment in the classroom may form students' perceived goal orientation, and the goal orientation of students may in turn generate various learning behaviors and outcomes (Peng et al. 2013). In line with literature on the significance of student motivation (Meece et al. 2006; Schuitema et al. 2014), scholars are calling for examining the 
mediating effect of learning goal orientation in linking the creative learning environment and student creativity.

As students learn in a group and/or classroom, interactions among each other may also be embedded in broader social networks; therefore, the ties among students within social networks can improve the quality of information received (Hommes et al. 2012). Network ties represent students' relations with their teachers and classmates within an academic environment (Chow and Chan 2008), which was found not only to be composed of factors in class but also to impact students' outcomes. Despite the attention given to the acknowledgment that encouraging personal interactions can benefit students more from diverse information exchange in generating creativity (Cheng 2011), knowledge on whether network ties can transmit the influence of a creative learning environment on student creativity is still limited.

Finally, scholars have acknowledged that when students are sharing their knowledge, they tend to utilize the knowledgebased resources in the classroom and after class to facilitate their creative activities (Yeh et al. 2012). Since creativity theoretically requires various types of knowledge and information (Amabile 2012), previous research has indicated that improving university students' creativity is based on knowledge-management, which involves the process of converting knowledge and creating new knowledge (Van Den Hooff and De Ridder 2004), as well as the process of sharing relevant information, ideas, suggestions, and expertise with others (Bartol and Srivastava 2002). However, studies thus far fail to provide a clear picture to evidence whether learning contexts may stimulate students' creativity via knowledge sharing. Taken together, we propose that learning goal orientation, network ties, and knowledge sharing can mediate the relationship between student creativity and a creative learning environment. Figure 1 shows the hypothesized model.

\section{Literature Review and Hypotheses Development}

\section{Creative Learning Environment and Student Creativity}

Creativity is generally conceptualized as individual's ability to generate new ideas (e.g., Amabile 1996; Liu 2017; Tsai et al.
2015). For example, Amabile's (2012) definition of creativity-i.e., the production of ideas that are both novel and useful - has been widely used in the educational research area. In the current study, we follow this line of literature, and define creativity in learning as the ability to create new robust ideas and novel ways of dealing with a learning problem, which emerge from discussion and interaction between peers (Rodriguez, Zhou, \& Carrió, 2017). To cultivate student's creativity in the context of classroom, scholars suggest to encourage students to ask more questions, to investigate the causes, effects, and consequences of their observations, and to generate more high-quality questions (Barrow, 2010). Accordingly, it is critical to understand how to effectively boost student creativity with regard to the learning context.

There is reasonable evidence from a number of studies indicating that creativity can be stimulated by contextual factors (Kozbelt et al. 2010). Among such factors as classroom interaction and teachers' positive behaviors and attitudes (Beghetto and Kaufman 2014), an important characteristic of teachers is strong facilitation skills. That is, teachers, as supportive facilitators, can inspire students to become intellectual risk-takers and creative problem solvers. Consistently, scholars suggest that creative learning is a key element in the creative process (Chappell and Craft 2011); thus, students need to be provided creative learning opportunities in the classroom environment (Richardson and Mishra 2018). Therefore, school environments that support and actively accelerate students' creative expression can promote students' engagement in creative activities (Davies et al. 2013; Tsai et al. 2015).

Based on the arguments above, the present study proposes a specific learning environment-i.e., a creative learning environment - that may directly boost students' creativity. A creative learning environment in class is characterized as valuing ideas, indicating that students are not only allowed but also encouraged to take sensible risks and make mistakes during the learning process (Mishra 2018); therefore, students are highly supported in reaching their creative potential (Chan and Yuen 2014). For example, in a review of a classroom learning environment, researchers found that when studying in a creative learning environment at school, students are likely to continue to develop their skills and professional knowledge, which significantly spurs the development of their creative

Fig. 1 The hypothesized model

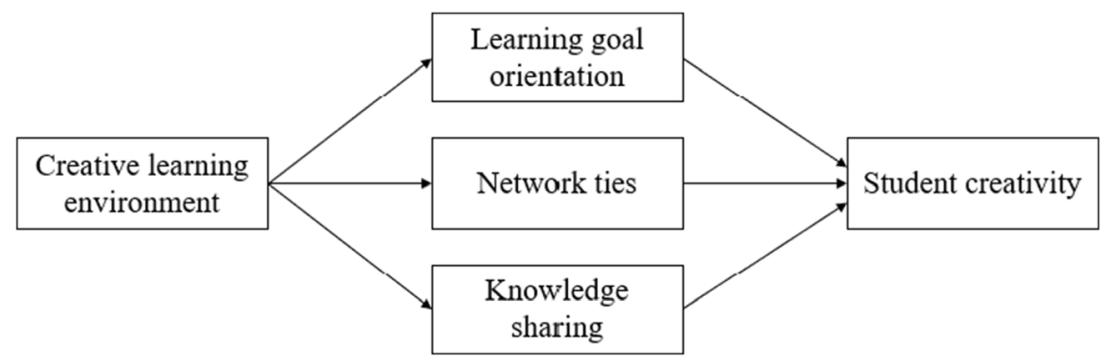


responses (Davies et al. 2013). As a result, students have more creative achievements (Mishra 2018). Thus, we propose the following hypothesis:

Hypothesis 1. The creative learning environment is positively related to student creativity.

\section{Learning Goal Orientation as a Mediator}

Goal orientation is the reason or purpose for a person's involvement in tasks (VandeWalle et al. 2001). Importantly, as a key dimension of individual goal orientation, learning goal orientation has been found to be formed by desirable environments (Schweder et al. 2019) and to benefit individuals' processes of producing creative outcomes (Malmberg 2008; VandeWalle et al. 2001). For example, scholars empirically illustrated that a learning environment (e.g., a classroom structure characterized as contingency-contract) facilitated students to set more learning goals (Self-Brown and Mathews 2003), which then increased individuals' effort investment towards more achievements(Pintrich 2000; Schweder et al. 2019). Considering the conceptual and empirical evidence, we propose learning goal orientation as a mediator in the relationship between student creativity and a creative learning environment. Since a creative learning environment is characterized as providing support and resources (Davies et al. 2013), individuals are given more opportunities to become interested in and enjoy a learning activity. Thus, when learning in this situation, it is emphasized that students can extend their abilities through greater effort (Richardson and Mishra 2018) and can seek out opportunities to practice and improve their skills (Lerang et al. 2019), leading to greater achievement.

Creative outputs, theoretically, require abilities and skills to generate novel ideas and solutions (Amabile 1996); therefore, learning and developing new knowledge are essential to be creative in class. Consistent with this stream of reasoning, scholars have claimed that an individual's learning goal orientation can stimulate actions to improve his or her creative competencies (Gong et al. 2009). That is, students who have a strong learning goal orientation act more proactively and respond positively to problems and challenges through their knowledge of learning (Chan and Yuen 2014). Consequently, these students may experience higher levels of internal motivation to devise creative ideas (Shin et al. 2012).

Taken together, we hypothesize the mediating effect of learning goal orientation in the creative learning environment-creativity relationship. Specifically, the space within a classroom that is capable of being used flexibly to promote students' learning can facilitate the development of learning goal orientation among students, which in turn offers them resources to become creative. Thus, we propose the following hypothesis:

Hypothesis 2. Learning goal orientation mediates the relationship between a creative learning environment and student creativity.

\section{Network Ties as a Mediator}

A glance at the academic and wider educational literature reveals that social capital emphasizes personal interactions in terms of social ties (Dawson 2008). Scholars specify that creating a creative learning environment in the classroom can promote interaction among students because they can observe an open mindset and good communication climate (Mishra 2018). For instance, researchers in the area of tie strength suggest that strong ties involve higher emotional closeness, whereas weak ties are more likely to be nonredundant connections and, thus, to be associated with nonredundant information (Granovetter 1977; Perry-Smith 2006). Thus, the space within a classroom that is capable of being used flexibly to promote students' learning can contribute to building their network ties.

Previous studies have also indicated that students' social capital is an important asset to promote their creativity (Eid and Al-Jabri 2016). Specifically, when students build personal ties within their surroundings (e.g., with classmates), they are more willing to make contact with other students because of their common interests in the classroom (Liu et al. 2017), which eventually increases their ability not only to solve problems but also to reformulate problems and solutions creatively. Moreover, it is clear that social network ties facilitate new connections among students and teachers, in that they provide individuals with an alternative way to connect with others who share their interests or relational goals (Ellison et al. 2006; Parks and Floyd 1996). These new connections may result in an increase in achieving their goal in a creative way (Beghetto 2010; Soh 2017).

Taken together, the mediator of network ties is proposed in the relationship between creativity and a creative learning environment. Specifically, when the class is characterized as promoting learning in a creative way, students are more likely to build a strong network tie. As a result, they tend to be connecting with others (e.g., classmates, and teachers) who may not only provide useful information or new perspectives but also emotional support (Ellison et al. 2007), and then put more efforts into creative activities. Thus, we propose the following hypothesis:

Hypothesis 3. Network ties mediate the relationship between creative learning environment and student creativity. 


\section{Knowledge Sharing as a Mediator}

Knowledge sharing is generally defined as activities through which various types of knowledge (e.g., information and skills) are exchanged and disseminated among people, units, communities, and/or organizations (Bukowitz and Williams 1999). Previous education literature has significantly highlighted the importance of knowledge sharing in the classroom (Eid and Al-Jabri 2016). Specifically, students accumulate their knowledge through integrating information, experience, and theory from their surroundings (Chang and Chuang 2011). That is, when students are studying in a learning environment characterized as having supportive relationships between teachers and learners, students are more likely to interact with others in the group and to share knowledge and experiences. As a result, their performance in class is significantly improved (Eid and Al-Jabri 2016). We therefore expect a positive effect of a creative learning environment on student knowledge sharing.

Based on the previous research findings, we further expect that knowledge sharing can stimulate student creativity in class. Specifically, the shared knowledge can improve individuals' capabilities of forming new knowledge, refining old knowledge, as well as synthesizing more knowledge in the future (Yeh et al. 2012). As researchers have suggested, the more knowledge is shared, the more nonoverlapping information emerges from other students within the group (Chow and Chan 2008; Eid and Al-Jabri 2016; Richter et al. 2012). In this situation, students can receive the benefits of collective wisdom, which provides information contributing to their explicit knowledge and subsequently enhancing their creativity (Yeh et al. 2012). Therefore, knowledge sharing can leverage students' engagement in creative activities.

Taken together, we argue that when students are learning in a conducive environment characterized as highlighting creative learning, they have more willingness to share their knowledge with their classmates; therefore, they have more opportunities to access to diverse knowledge and information, which trigger their creative ideas to solve problems. Thus, we propose the following hypothesis:

Hypothesis 4. Knowledge sharing mediates the relationship between a creative learning environment and student creativity.

\section{Method}

\section{Sample and Procedure}

The participants in the current research were 431 undergraduates in their third year of studies and their teachers from a university in the central region of P.R. China. Before submitting our questionnaires to the undergraduate students, one of the authors asked the dean of the university about whether creativity is encouraged in the classroom. We received the information that creativity was present throughout the courses in all projects and work carried out in School of Business, especially in the two departments-i.e., department of tourism management and department of business administration. Students in the two majors were educated to pursue creative, problem-solving and flexible capabilities that today's employers demand. Specifically, educators have practically highlighted, and scholars have theoretically found that creativity is significantly required for students both in tourism management and business administration majors (e.g., Blau et al. 2019; Liu 2017).

Next, the teachers of undergraduate students in the two departments also sent us the confirmation that they not only paid attention to help students develop creative problemsolving skills, but also encouraged students in the class to be creative in learning. Afterwards, teachers were asked to help collect data. Specifically, questionnaires were sent to 440 undergraduate students during their classes, and they were asked to complete the survey. The participants were completely unaware of the goals and aims of the research, and they did not have any prior training in creativity. The teacher in the class announced that all the questionnaires were confidential and would be used only for research. None of the items on the scale had correct answers; the students were to answer each item according to their own perceptions. Subsequently, the teacher received all the questionnaires; and then the teacher rated each student's creativity. Finally, the teacher sent all the questionnaires to one of the authors directly.

After deleting nine incomplete questionnaires, we received 431 validate responses from undergraduate students (98\% response rate). In total, $69.7 \%$ of the students were female; $41.8 \%$ of the students majored in tourism management, and $58.2 \%$ majored in business administration.

\section{Measurements}

In order to obtain reliable information from the respondents, existing measures with established validity and reliability from previous literature were selected to operationalize all constructs in our study. In addition, all the scales were widely used in education and creativity research fields. All the variables are assessed with a 5-point Likert-type scale $(1=$ totally disagree; $5=$ totally agree). We used the back-translation procedure (Brislin 1986) to translate the English version into a Chinese version. The specific measurements of these constructs' reliability and convergent validity can be found in Appendix Table 1. 


\section{Creative Learning Environment}

The creative learning environment was adapted from Richardson and Mishra (2018) and measured using 14 items to portray students' perceptions of the creative learning environment in the class. An example of items is "Multiple ways of knowing and learning are encouraged in class". The scale had a reliability of 0.91 .

\section{Learning Goal Orientation}

Following previous studies (Lerang et al. 2019), the scale with four items adapted (Skaalvik 1997) was used to assess students' learning orientation in the current study $\left(\chi^{2} / d f=3.35 / 2\right.$; $\mathrm{TLI}=0.98 ; \mathrm{CFI}=0.99 ;$ RMSEA $=0.04)$. An example of items is "In class I want to learn something new". The scale had a reliability of 0.90 .

\section{Knowledge Sharing}

A 3-item scale (Yeh et al. 2012) was used to measure knowledge sharing. "In my class I know who I can contact for specific questions," is an example of a question from this measure. The scale had a reliability of 0.88 .

\section{Creativity-Enhancing Network Activities}

Reflecting students' creativity-enhancing network activities with their classmates, network ties were assessed using a three-item scale (Chow and Chan 2008). An example of items is "In general, I have a very good relationship with my classmates". The scale had a reliability of 0.92 .

\section{Student Creativity}

The teacher was asked to rate student creativity with a 4-item creativity scale (Farmer et al. 2003). An example of items is "This student seeks new ideas and ways to solve problems". The scale had a reliability of 0.86 .

\section{Control Variables}

Following previous studies (e.g., Peng et al. 2013; Schweder et al. 2019), we controlled for students' age (in years) since past research has indicated that individual learning may vary across student ages. Moreover, because these participants (i.e., students) are from different research backgrounds, we controlled their major $(1=$ tourism management; $2=$ business administration).

\section{Analytical Strategy}

We first conducted preliminary analyses to establish the factors' discriminant validity in the current study. Furthermore, we tested our hypotheses using a PROCESS program developed by Preacher et al. (2007) in SPSS because it facilitates path analysis-based moderation analyses as well as their combination as a "conditional process model" by using ordinary least squares (OLS) regression. Specifically, we, in the first step, test the mediation effects through applying OLS regression analyses in the PROCESS program to generate the direct and indirect effects. In the next step, as several methodologists have recently recommended using a bootstrap approach to obtain confidence intervals (CIs), we tested the mediation hypothesis through a bootstrapping procedure with 10,000 samples. Since this research aims to unfold the different mechanisms in the creative learning environment-creativity association, in the following analyses, we controlled for other mediators, testing a specific mediator to further validate the mediating effects.

\section{Results}

\section{Preliminary Analyses}

Before testing hypotheses, we conducted a confirmatory factor analysis (CFA) to examine discriminate validity using AMOS 21.0. The results are shown in Appendix Table 2. We evaluated the fit of our models based on five primary fit indices, as suggested by $\mathrm{Hu}$.

Bentler (1999): the $\chi^{2}$ test of model fit, the root mean square error of approximation (RMSEA) with its respective confidence intervals, the comparative fit index (CFI), and the Tucker-Lewis index (TLI). The results show that the hypothesized five-factor model provided a better fit to the data $\left(\chi^{2}[198]=323.82, \mathrm{CFI}=0.99\right.$, TLI $=0.98$, RMSEA $=0.04)$ than other alternative models $(\mathrm{Hu}$ and Bentler 1999): a three-factor model combining network ties and knowledge sharing $\left(\chi^{2}[236]=1748.77\right.$, CFI $=$ $0.84, \mathrm{TLI}=0.81$, RMSEA $=0.12$ ), a two-factor model combining learning goal orientation, network ties, and knowledge sharing $\left(\chi^{2}[238]=1931.58, \mathrm{CFI}=0.82\right.$, $\mathrm{TLI}=0.79$, RMSEA $=0.13$ ), and a one-factor model combining all the variables $\left(\chi^{2}[241]=2444.94, C F I=0.77\right.$, $\mathrm{TLI}=0.73$, RMSEA $=0.15$ ).

Appendix Table 3 shows the descriptive statistics, bivariate correlations, and Cronbach's alphas for all the variables.

\section{Hypotheses Testing}

To test the hypotheses, we employed an SPSS macro program (Hayes 2012) to estimate the mediation effects. 
Specifically, we used Model 4 in PROCESS, which generates direct and indirect effects in mediation, where total effects, direct effects and indirect effects are estimated by means of OLS regression analyses. Appendix Table 4 shows the results.

Regarding testing H1, in Model 1, the creative learning environment was positively associated with student creativity $(\beta=0.79, p<0.001)$, supporting $\mathrm{H} 1$. Regarding testing $\mathrm{H} 2, \mathrm{H} 3$ and $\mathrm{H} 4$, in Model 2, the creative learning environment was positively associated with learning goal orientation $(\beta=0.45, p<0.001)$ after controlling network ties and knowledge sharing. In Model 3, the creative learning environment was positively associated with network ties $(\beta=0.33, p<0.001)$ after controlling learning goal orientation and knowledge sharing. In Model 4, creative learning environment was positively associated with knowledge sharing $(\beta=0.14, p<0.05)$ after controlling learning goal orientation and network ties. Moreover, when the independent variable (i.e., creative learning environment) and the three mediators (i.e., learning goal orientation, network ties, and knowledge sharing) were entered in the regression model (i.e., Model 5), the independent variable (learning goal orientation, $\beta=0.25, p<0.001$; network ties, $\beta=0.033, p<$ 0.001 ; knowledge sharing, $\beta=0.14, p<0.001$ ) and the mediators were positively related to student creativity. That is, the relationship between the creative learning environment and creativity was partially mediated by the three mediators.

To further examine the mediating effects, we conducted a bias-corrected bootstrap (10,000 resamples) analysis. The results (in Appendix Table 5) showed that the indirect effect of the creative learning environment on creativity through learning goal orientation was $0.11(95 \% \mathrm{CI}=$ $0.064,0.163$ ), supporting $\mathrm{H} 2$; through network ties was $0.11(95 \% \mathrm{CI}=0.056,0.170)$, supporting $\mathrm{H} 3$; and through knowledge sharing was $0.02(95 \% \mathrm{CI}=0.001,0.049)$, supporting H4.

\section{Discussion}

Aiming at opening the black box of how a creative learning environment can contribute to student creativity, the current study proposes and tests a mediation model that examines the relationship between a creative learning environment and student creativity through multiple intervening mechanisms. The results show that a creative learning environment is positively related to student creativity through improving students' learning goal orientation, knowledge sharing, and network ties concurrently.

\section{Theoretical Implications}

The main aim of the present study was to investigate how a creative learning environment can foster student creativity in class through multiple intervening mechanisms. There are several implications of this study that will enrich the current literature. First, this study fills the gap regarding the potential influence of a creative learning environment on creativity. Although previous studies have conceptually suggested that a learning environment that promotes creative activities in class boosts students' academic outcomes (Davies et al. 2013; Richardson and Mishra 2018), there is less empirical evidence to establish the benefits for creativity. Thus, this study answers scholars' call to "provide clear evidence of the effectiveness of creative learning environments" (Davies et al. 2013, p.89) by theorizing about the positive influences of a creative learning environment on undergraduate students' creativity.

Moreover, this study represents one of the first attempts to simultaneously examine distinct mechanisms from a different perspective to explain how a creative learning environment elicits student creativity. Specifically, drawing on the dynamic componential mod$\mathrm{el}$, the findings extend the current understanding of learning goal orientation, network ties, and knowledge sharing as distinct mediators. In recent years, scholars have increasingly argued that identifying multiple mechanisms can comprehensively reveal the effectiveness of contextual predictors for creativity (Amabile and Pratt 2016). Nevertheless, few studies have either explored the possibilities of various mediators simultaneously or focused on undergraduate students' creativity. This study deepens our understanding of the processes involved in generating student creativity in which a creative learning environment can increase students' learning goal orientation, network ties, and knowledge sharing concurrently to further boost their creativity.

\section{Educational Implications}

According to the findings, creating a learning environment should consider creative aspects to effectively enhance student creativity in class. Specifically, teachers can encourage students to learn and think creatively (e.g., taking risks, building free and open communication channels, supporting creative ideas, and allowing more freedom and choice while students complete their assignments). Moreover, as students' learning goal orientation, network ties, and knowledge sharing are key mediators for transferring the benefits of a creative learning environment, teachers should place value on the understanding of 
concepts and emphasize student effort over course grades (Lerang et al. 2019). In doing so, teachers can build students' learning goal orientations more in the direction of creative achievement. Regarding the development of students' network ties, they can be provided with training programs to develop their abilities to manage individual social connections and those of others, thus enabling them to study effectively while developing collaboration skills in class. Finally, teachers can consistently highlight the importance of exchanging and sharing new knowledge, which can help students acquire novel information to enhance their learning processes and effectiveness in a creative manner.

\section{Limitations}

There are several limitations in this research. First, the crosssectional research design cannot entirely rule out the problem of causality (e.g., student creativity may facilitate the process of building a creative learning environment in class). Thus, future research can employ more sophisticated testing to determine the direction of causality. Second, as the findings indicated the partial mediation effects, studies in the future can include other mediators (e.g., collective learning behaviors) that may comprehensively explain the effectiveness of a creative learning environment on student creativity. Finally, regarding the sample of undergraduate students in China in the present study, further research with other samples (e.g., postgraduate students) can extend the generalizability of the findings.

\section{Conclusion}

As providing education on creativity is a major challenge and a high priority for future course design for students, determining how to boost student creativity has been the subject of scholars' attention. This study proposes and examines whether and how multiple mechanisms can mediate the effect of a creative learning environment on undergraduate creativity. The research findings indicate that a creative learning environment can significantly enhance students' learning goal orientation, network ties, and knowledge sharing, which in turn facilitate their creativity. The direct implication is that researchers and educators should be more concerned about building creative learning environments and helping students in their development of a learning goal orientation, network ties, and knowledge sharing.

Acknowledgements This research was funded by supported by the Fundamental Research Funds for the Central Universities (grant number WK2160000013).

\section{Compliance with Ethical Standards}

Conflict of Interest The authors declare that they have no conflict of interest to disclose.

Ethical Approval All procedures performed in studies involving human participants were in accordance with the ethical standards of the institutional and/or national research committee and with the 1964 Helsinki declaration and its later amendments or comparable ethical standards.

Informed Consent Informed consent was obtained from all individual participants included in the study.

\section{Appendix}

Table 1 Reliability and convergent validity of variables

\begin{tabular}{|c|c|c|c|c|c|}
\hline Latent variable & Items & $\begin{array}{l}\text { Factor } \\
\text { loading }\end{array}$ & $\begin{array}{l}\text { Cronbach's } \\
\text { alpha }\end{array}$ & $\mathrm{CR}^{1}$ & $\mathrm{AVE}^{2}$ \\
\hline \multirow{14}{*}{$\begin{array}{c}\text { Creative learning } \\
\text { environment }\end{array}$} & CLE1 & 0.81 & \multirow[t]{14}{*}{0.91} & \multirow[t]{14}{*}{0.65} & \multirow[t]{14}{*}{0.83} \\
\hline & CLE2 & 0.83 & & & \\
\hline & CLE3 & 0.86 & & & \\
\hline & CLE4 & 0.77 & & & \\
\hline & CLE5 & 0.85 & & & \\
\hline & CLE6 & 0.78 & & & \\
\hline & CLE7 & 0.82 & & & \\
\hline & CLE8 & 0.80 & & & \\
\hline & CLE9 & 0.84 & & & \\
\hline & CLE10 & 0.79 & & & \\
\hline & CLE11 & 0.88 & & & \\
\hline & CLE12 & 0.76 & & & \\
\hline & CLE13 & 0.83 & & & \\
\hline & CLE14 & 0.79 & & & \\
\hline \multirow{4}{*}{$\begin{array}{l}\text { Learning goal } \\
\text { orientation }\end{array}$} & LGO1 & 0.81 & \multirow[t]{4}{*}{0.90} & \multirow[t]{4}{*}{0.66} & \multirow[t]{4}{*}{0.87} \\
\hline & LGO2 & 0.75 & & & \\
\hline & LGO3 & 0.80 & & & \\
\hline & LGO4 & 0.82 & & & \\
\hline \multirow[t]{3}{*}{ Knowledge sharing } & KS1 & 0.81 & \multirow[t]{3}{*}{0.88} & \multirow[t]{3}{*}{0.59} & \multirow[t]{3}{*}{0.90} \\
\hline & $\mathrm{KS} 2$ & 0.79 & & & \\
\hline & $\mathrm{KS} 3$ & 0.77 & & & \\
\hline \multirow[t]{3}{*}{ Network ties } & NT1 & 0.86 & \multirow[t]{3}{*}{0.92} & \multirow[t]{3}{*}{0.67} & \multirow[t]{3}{*}{0.81} \\
\hline & NT2 & 0.80 & & & \\
\hline & NT3 & 0.75 & & & \\
\hline \multirow[t]{4}{*}{ Creativity } & $\mathrm{C} 1$ & 0.80 & \multirow[t]{4}{*}{0.86} & \multirow[t]{4}{*}{0.63} & \multirow[t]{4}{*}{0.85} \\
\hline & $\mathrm{C} 2$ & 0.74 & & & \\
\hline & $\mathrm{C} 3$ & 0.79 & & & \\
\hline & $\mathrm{C} 4$ & 0.81 & & & \\
\hline
\end{tabular}

$\mathrm{CR}^{1}$ : Composite Reliability

$\mathrm{AVE}^{2}$ : Average Variance Extracted 
Table 2 Results of CFA: Comparison of measurement models

Table 3 Means, standard deviations, and zero-order correlations between study variables

\begin{tabular}{|c|c|c|c|c|c|}
\hline Model & $\chi^{2}$ & $d f$ & CFI & TLI & RMSEA \\
\hline $\begin{array}{l}\text { Five factors (baseline model): Creative learning environment, } \\
\text { learning goal orientation, knowledge sharing, network ties, } \\
\text { and creativity }\end{array}$ & 323.82 & 198 & 0.99 & 0.98 & 0.04 \\
\hline Four factors: knowledge sharing and network ties combined & 1553.26 & 230 & 0.87 & 0.87 & 0.12 \\
\hline $\begin{array}{l}\text { Three factors: knowledge sharing and network ties combined, } \\
\text { creative learning environment and creativity combined }\end{array}$ & 1748.77 & 236 & 0.84 & 0.81 & 0.12 \\
\hline $\begin{array}{l}\text { Two factors: learning goal orientation, knowledge sharing, and } \\
\text { network ties combined, creative learning environment and } \\
\text { creativity combined }\end{array}$ & 1931.58 & 238 & 0.82 & 0.79 & 0.13 \\
\hline One factor: All variables combined & 2444.94 & 241 & 0.77 & 0.73 & 0.15 \\
\hline
\end{tabular}

\begin{tabular}{llllllllll}
\hline & Mean & SD & 1 & 2 & 3 & 4 & 5 & 6 & 7 \\
\hline 1. Gender & 1.70 & 0.47 & & & & & & & \\
2. Major & 1.58 & 0.49 & 0.04 & & & & & & \\
3. Creative learning & 3.77 & 0.96 & $0.11^{*}$ & 0.07 & $(0.91)$ & & & & \\
$\quad$ environment & & & & & & & & & \\
4. Learning goal orientation & 4.16 & 1.14 & 0.05 & 0.05 & $0.39^{* *}$ & $(0.90)$ & & & \\
5. Network ties & 4.07 & 1.19 & 0.03 & -0.00 & $0.25^{* *}$ & $0.47^{* *}$ & $(0.92)$ & & \\
6. Knowledge sharing & 4.08 & 1.10 & $0.12^{* *}$ & 0.07 & $0.16^{* * *}$ & $0.19^{* * *}$ & $0.34^{* *}$ & $(0.88)$ & \\
7. Creativity & 4.15 & 1.03 & 0.06 & 0.19 & $0.37^{* *}$ & $0.28^{* *}$ & $0.46^{* *}$ & $0.58^{* * *}$ & $(0.86)$ \\
\hline
\end{tabular}

$N=431$

${ }^{*} p<0.05 .{ }^{* *} p<0.01$

Table 4 Results of the mediation regression analyses

\begin{tabular}{|c|c|c|c|c|c|}
\hline Variables & $\begin{array}{l}\text { Model } 1 \\
\text { Creativity }\end{array}$ & $\begin{array}{l}\text { Model } 2 \\
\text { Learning } \\
\text { orientation }\end{array}$ & $\begin{array}{l}\text { Model } 3 \\
\text { Network ties }\end{array}$ & $\begin{array}{l}\text { Model } 4 \\
\text { Knowledge sharing }\end{array}$ & $\begin{array}{l}\text { Model } 5 \\
\text { Creativity }\end{array}$ \\
\hline Constant & $1.34^{* * * *}$ & 0.21 & $0.72^{* * *}$ & $0.51^{*}$ & $0.50^{* * * *}$ \\
\hline Gender & -0.04 & -0.10 & -0.09 & $0.18^{*}$ & -0.01 \\
\hline Subject & -0.07 & 0.02 & -0.13 & 0.07 & -0.04 \\
\hline Creative learning environment & $0.79^{* * * *}$ & $0.45^{\text {****** }}$ & $0.33^{* * * * *}$ & $0.14^{*}$ & $0.21^{* * * *}$ \\
\hline Learning goal orientation & & & $0.39^{* * * * *}$ & $0.46^{* * * * *}$ & $0.25^{* * * *}$ \\
\hline Network ties & & $0.26^{\text {***** }}$ & & $0.18^{* * * *}$ & $0.33^{* * * *}$ \\
\hline Knowledge sharing & & $0.34^{* * * *}$ & $0.20^{* * * *}$ & & $0.14^{* * * *}$ \\
\hline $\mathrm{R}^{2}$ & 0.54 & 0.69 & 0.55 & 0.54 & 0.55 \\
\hline $\mathrm{F}$ & $166.44^{* * * *}$ & $188.16^{* * * * *}$ & $104.86^{* * * *}$ & $100.68^{* * * *}$ & $104.86^{* * *}$ \\
\hline
\end{tabular}

Note. $N=431$

${ }^{*} p<00.05 .^{* *} p<0.01 .{ }^{* * * *} p<0.001$

Table 5 Direct and indirect effects of a creative learning environment on creativity through mediators

\begin{tabular}{|c|c|c|c|c|c|c|c|}
\hline \multicolumn{4}{|c|}{ Direct effect } & \multicolumn{4}{|l|}{ Indirect effect } \\
\hline Effect & se & $\mathrm{t}$ & $95 \% \mathrm{CI}$ & & se & $\mathrm{t}$ & $95 \% \mathrm{CI}$ \\
\hline \multirow[t]{3}{*}{$0.21^{* * * *}$} & 0.40 & 5.25 & $\begin{array}{l}0.133 \\
0.291\end{array}$ & $\begin{array}{l}\text { Mediator: Learning goal } \\
\text { orientation }\end{array}$ & $0.11^{* * * *}$ & 0.03 & $\begin{array}{l}0.064, \\
0.163\end{array}$ \\
\hline & & & & Mediator: Network ties & $0.11^{* * * *}$ & 0.03 & $\begin{array}{r}0.056 \\
0.170\end{array}$ \\
\hline & & & & Mediator: Knowledge sharing & $0.02^{* * *}$ & 0.01 & $\begin{array}{r}0.001 \\
0.049\end{array}$ \\
\hline
\end{tabular}

$N=431$. Based on 10,000 bootstrapping samples

${ }^{*} p<00.05$. $^{* *} p<0.01 .^{* * *} p<0.001$ 
Open Access This article is licensed under a Creative Commons Attribution 4.0 International License, which permits use, sharing, adaptation, distribution and reproduction in any medium or format, as long as you give appropriate credit to the original author(s) and the source, provide a link to the Creative Commons licence, and indicate if changes were made. The images or other third party material in this article are included in the article's Creative Commons licence, unless indicated otherwise in a credit line to the material. If material is not included in the article's Creative Commons licence and your intended use is not permitted by statutory regulation or exceeds the permitted use, you will need to obtain permission directly from the copyright holder. To view a copy of this licence, visit http://creativecommons.org/licenses/by/4.0/.

\section{References}

Amabile, T. M. (1996). Creativity and innovation in organizations. Boston: Harvard Business School Press.

Amabile, T. M. (2012). Componential theory of creativity. Harvard Business School, 12(96), 1-10.

Amabile, T. M., \& Pratt, M. G. (2016). The dynamic componential model of creativity and innovation in organizations: Making progress, making meaning. Research in Organizational Behavior, 36, 157183.

Bartol, K. M., \& Srivastava, A. (2002). Encouraging knowledge sharing: The role of organizational reward systems. Journal of Leadership and Organizational Studies, 9(1), 64-76.

Beghetto, R. A. (2010). Creativity in the classroom. In J. C. Kaufman \& R. J. Sternberg (Eds.), The Cambridge handbook of creativity (447463). New York, NY: Cambridge University Press.

Beghetto, R. A., \& Kaufman, J. C. (2014). Classroom contexts for creativity. High Ability Studies, 25(1), 53-69.

Blau, G., Williams, W., Jarrell, S., \& Nash, D. (2019). Exploring common correlates of business undergraduate satisfaction with their degree program versus expected employment. The Journal of Education for Business, 94(1), 31-39.

Brislin, R. W. (1986). The wording and translation of research instruments. In W. J. Lonner \& J. W. Berry (Eds.), Field methods in cross-cultural research (pp. 137-164). Beverley Hills, CA: Sage.

Bukowitz, W. R., \& Williams, R. L. (1999). The knowledge management fieldbook. Prentice Hall, Upper Saddle River, NJ: Financial times/ prentice hall.

Chan, S., \& Yuen, M. (2014). Personal and environmental factors affecting teachers' creativity-fostering practices in Hong Kong. Thinking Skills and Creativity, 12, 69-77.

Chang, H. H., \& Chuang, S.-S. (2011). Social capital and individual motivations on knowledge sharing: Participant involvement as a moderator. Information \& Management, 48(1), 9-18.

Chappell, K., \& Craft, A. (2011). Creative learning conversations: Producing living dialogic spaces. Educational Research, 53(3), 363-385.

Cheng, V. M. (2011). Infusing creativity into eastern classrooms: Evaluations from student perspectives. Thinking Skills and Creativity, 6(1), 67-87.

Chow, W. S., \& Chan, L. S. (2008). Social network, social trust and shared goals in organizational knowledge sharing. Information \& Management, 45(7), 458-465.

D'Lima, G. M., Winsler, A., \& Kitsantas, A. (2014). Ethnic and gender differences in first-year college students' goal orientation, self-efficacy, and extrinsic and intrinsic motivation. The Journal of Educational Research, 107(5), 341-356.

Davies, D., Jindal-Snape, D., Collier, C., Digby, R., Hay, P., \& Howe, A. (2013). Creative learning environments in education-A systematic literature review. Thinking Skills and Creativity, 8, 80-91.
Dawson, S. (2008). A study of the relationship between student social networks and sense of community. Journal of Educational Technology \& Society, 11(3), 224-238.

Eid, M. I., \& Al-Jabri, I. M. (2016). Social networking, knowledge sharing, and student learning: The case of university students. Computers \& Education, 99, 14-27.

Ellison, N., Heino, R., \& Gibbs, J. (2006). Managing impressions online: Self-presentation processes in the online dating environment. Journal of Computer-Mediated Communication, 11(2), 415-441.

Ellison, N. B., Steinfield, C., \& Lampe, C. (2007). The benefits of Facebook "friends:" social capital and college students' use of online social network sites. Journal of Computer-Mediated Communication, 12(4), 1143-1168.

Farmer, S. M., Tierney, P., \& Kung-Mcintyre, K. (2003). Employee creativity in Taiwan: An application of role identity theory. Academy of Management Journal, 46(5), 618-630.

Gong, Y., Huang, J.-C., \& Farh, J.-L. (2009). Employee learning orientation, transformational leadership, and employee creativity: The mediating role of employee creative self-efficacy. Academy of Management Journal, 52(4), 765-778.

Granovetter, M. S. (1977). The strength of weak ties Social networks (pp. 347-367): Elsevier.

Hayes, A. F. (2012). PROCESS: A versatile computational tool for observed variable mediation, moderation, and conditional process modeling. Kansas: University of Kansas.

Hommes, J., Rienties, B., de Grave, W., Bos, G., Schuwirth, L., \& Scherpbier, A. (2012). Visualising the invisible: A network approach to reveal the informal social side of student learning. Advances in Health Sciences Education, 17(5), 743-757.

$\mathrm{Hu}$, L. t., \& Bentler, P. M. (1999). Cutoff criteria for fit indexes in covariance structure analysis: Conventional criteria versus new alternatives. Structural Equation Modeling: A Multidisciplinary Journal, $6(1), 1-55$.

Kozbelt, A., Beghetto, R. A., \& Runco, M. A. (2010). Theories of creativity. The Cambridge Handbook of Creativity, 2, 20-47.

Lerang, M. S., Ertesvåg, S. K., \& Havik, T. (2019). Perceived classroom interaction, goal orientation and their association with social and academic learning outcomes. Scandinavian Journal of Educational Research, 63(6), 913-934.

Liu, C. H. S. (2017). Remodelling progress in tourism and hospitality students' creativity through social capital and transformational leadership. Journal of Hospitality, Leisure, Sport \& Tourism Education, 21, 69-82.

Liu, S., Zhu, M., Yu, D. J., Rasin, A., \& Young, S. D. (2017). Using realtime social media technologies to monitor levels of perceived stress and emotional state in college students: A web-based questionnaire study. JMIR Mental Health, 4(1), e2.

Malmberg, L.-E. (2008). Student teachers' achievement goal orientations during teacher studies: Antecedents, correlates and outcomes. Learning and Instruction, 18(5), 438-452.

Meece, J. L., Anderman, E. M., \& Anderman, L. H. (2006). Classroom goal structure, student motivation, and academic achievement. Annual Review of Psychology, 57, 487-503.

Mishra, B. (2018). The organizational learning inventory: An assessment guide for understanding your institution's learning capabilities. The Learning Organization, 25(6), 455-456.

Parks, M. R., \& Floyd, K. (1996). Making friends in cyberspace. Journal of Computer-Mediated Communication, 1(4), JCMC144.

Peng, S.-L., Cherng, B.-L., Chen, H.-C., \& Lin, Y.-Y. (2013). A model of contextual and personal motivations in creativity: How do the classroom goal structures influence creativity via self-determination motivations? Thinking Skills and Creativity, 10, 50-67.

Perry-Smith, J. E. (2006). Social yet creative: The role of social relationships in facilitating individual creativity. Academy of Management Journal, 49(1), 85-101. 
Pintrich, P. R. (2000). Multiple goals, multiple pathways: The role of goal orientation in learning and achievement. Journal of Educational Psychology, 92(3), 544-555.

Preacher, K. J., Rucker, D. D., \& Hayes, A. F. (2007). Addressing moderated mediation hypotheses: Theory, methods, and prescriptions. Multivariate Behavioral Research, 42(1), 185-227.

Richardson, C., \& Mishra, P. (2018). Learning environments that support student creativity: Developing the SCALE. Thinking Skills and Creativity, 27, 45-54.

Richter, A. W., Hirst, G., Van Knippenberg, D., \& Baer, M. (2012). Creative self-efficacy and individual creativity in team contexts: Cross-level interactions with team informational resources. Journal of Applied Psychology, 97(6), 1282-1290.

Schuitema, J., Peetsma, T., \& van der Veen, I. (2014). Enhancing student motivation: A longitudinal intervention study based on future time perspective theory. The Journal of Educational Research, 107(6), 467-481.

Schweder, S., Raufelder, D., Kulakow, S., \& Wulff, T. (2019). How the learning context affects adolescents' goal orientation, effort, and learning strategies. The Journal of Educational Research, 112(5), 604-614.

Self-Brown, S. R., \& Mathews, S. (2003). Effects of classroom structure on student achievement goal orientation. The Journal of Educational Research, 97(2), 106-112.

Shin, S. J., Kim, T.-Y., Lee, J.-Y., \& Bian, L. (2012). Cognitive team diversity and individual team member creativity: A cross-level interaction. Academy of Management Journal, 55(1), 197-212.
Skaalvik, E. M. (1997). Self-enhancing and self-defeating ego orientation: Relations with task and avoidance orientation, achievement, self-perceptions, and anxiety. Journal of Educational Psychology, 89(1), 71-81.

Soh, K. (2017). Fostering student creativity through teacher behaviors. Thinking Skills and Creativity, 23, 58-66.

Tsai, C.-Y., Horng, J.-S., Liu, C.-H., Hu, D.-C., \& Chung, Y.-C. (2015). Awakening student creativity: Empirical evidence in a learning environment context. Journal of Hospitality, Leisure, Sport \& Tourism Education, 17, 28-38.

Van den Hooff, B., \& De Ridder, J. A. (2004). Knowledge sharing in context: The influence of organizational commitment, communication climate and CMC use on knowledge sharing. Journal of Knowledge Management, 8(6), 117-130.

VandeWalle, D., Cron, W. L., \& Slocum Jr., J. W. (2001). The role of goal orientation following performance feedback. Journal of Applied Psychology, 86(4), 629-640.

Yeh, Y.-C., Yeh, Y.-L., \& Chen, Y.-H. (2012). From knowledge sharing to knowledge creation: A blended knowledge-management model for improving university students' creativity. Thinking Skills and Creativity, 7(3), 245-257.

Publisher's Note Springer Nature remains neutral with regard to jurisdictional claims in published maps and institutional affiliations. 